\title{
David Ho
}

Credited with some of the biggest breakthroughs in tackling HIV/AIDS, David Ho has been a star from the beginning. But in a field fraught with controversy, fame may have come at a cost.

You might say David Ho is a celebrity in science. Ho has been former basketball star Magic Johnson's physician since 1991. When Ho was just 37, Hollywood producer Irene Diamond hand-picked him to run the Aaron Diamond AIDS Research Center (ADARC) in New York. Most famously, he edged out Bill Clinton, Bill Gates and Mother Teresa to become Time's Person of the Year for 1996.

But as with any celebrity, rumors swirl around Ho-most of them about a particularly acrimonious period at the ADARC. During the late 1990s, several investigators at the center-most of them now renowned in their own right - left under unpleasant circumstances. Many of those approached to comment on Ho declined and only a few agreed to be quoted, on condition of anonymity.

Ho is perhaps best known for showing in 1996 that combining antiretroviral drugs can drive HIV down to undetectable levels. The finding made a splash at that year's International AIDS Conference in Vancouver. "It was hard to go to that meeting and avoid being the center of attention because the data were striking," Ho recalls. "I just remember that there were a lot of people approaching us. That period, it seems like a blur."

Among scientists, Ho is more famous for a series of high-profile papers - that many say are among the best in AIDS research-on viral replication and dynamics. "David's work really gave us the first major insights into the dynamics of HIV infection in humans," says Joseph Sodroski, professor of pathology at Harvard Medical School. "I think those are still very important contributions to our thinking."

Ho trained in physics and biology as an undergraduate at Caltech, then spent 18 months in a quantitative health sciences program at Harvard Medical School. As a resident at Cedars-Sinai Medical Center in Los Angeles, he also saw some of the first AIDS patients in the US. That diverse training served him well when he began tackling HIV in the lab.

When Ho came back to Harvard from Cedars-Sinai, he joined Marty Hirsch's lab at Massachusetts General Hospital. Those were productive years. "I don't want to take too much credit. It was a new field, it was wide open and everything we found was publishable," Ho says. "But for the rest of my life, I will credit that environment for nurturing me."

Ho's tenure at ADARC has been equally productive. From a relatively new entity in 1991, the center has become one of the premier AIDS research institutes in the world. But the atmosphere inside the center has been, at times, less nurturing.

Those who worked at the ADARC in the late 1990s say that intense, sometimes ugly, internal competition and serious personality conflictssome culminating in yelling matches-soured the intellectual atmosphere at the lab. "I get nauseous when I think about working there, it brings back memories I'd rather leave behind," says one researcher who did not wish to be identified, saying he feared repercussions on his career. "It was an atmosphere of poison ... a culture of war."

Ho is reluctant to talk about that time, but says things were unpleasant. "There was a time when people yelled at each other. I was caught in the middle of all of them," he says. "In many ways, I regret all that."

By all accounts, the center was too small to accommodate so many driven and gifted researchers. Ned Landau, who worked at the ADARC from 1991 to 1998, says a more assertive director might have better managed the conflicts. "David's style of leadership was ... to approach conflict in a gentle, persuasive manner," Landau says. "Maybe what it required is a really strong leader who said, 'this is the way it's going to be."'

Landau says his years at the center were "extremely difficult" but, ultimately, they helped launch his career and many others. "I think that's the key measure," he says. "It's not a matter of whether everyone was feeling happy and feeling good about the place."

Some researchers say the animosity toward Ho may be driven at least in part by envy. "In general in this field, people don't take kindly to [other] people getting visible and [winning] accolades," says Sodroski. "It's not that altruistic of a field."

The Time cover took many people, including Ho, by surprise. The magazine had covered Ho's work on viral dynamics the previous year, so when reporters approached him again, Ho says, he assumed it was for a follow-up. It wasn't until they kept coming back, and brought photographers, that he realized it was something bigger. When he finally heard the news a week before publication, he fled with his family to Vermont.

That year, he now says, the magazine was trying to celebrate the advances in understanding and treating AIDS. "I think they recognized that I had my hand in a couple of those things," he says. Although he knew the magazine often picks one person to represent the achievements of a field, Ho says he was uncomfortable assuming a symbolic role. "It should have been a happy event, but it was filled with anxiety," he says. "I thought that there would also be a backlash and there is."

"There was a time when
people yelled at each other.
I was caught in the middle
of all of them. In many
ways, I regret all that."

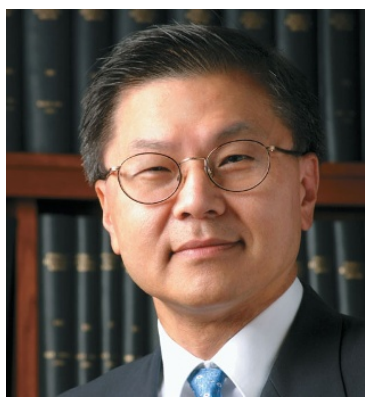

The ensuing attention has so complicated Ho's life that he has hired a publicist to screen requests for interviews. "I try very hard to speak up only when I have something new to say," he says. Still, articles about Ho tend to repeat a few key stories-that he arrived in the US from Taiwan when he was 12 and didn't speak any English, for instance, or that his name derives from the Chinese characters Da-i, literally 'big one'.

Ho says that in some ways, the notoriety has been bad for his academic career. Although he has served as chair of the retrovirus conference for the past three years, he has been less visible in basic research, directing most of his effort to an AIDS vaccine. Ho only began his vaccine work in 2001, but one candidate is already in phase 1 trials and another is set to begin later this year. "How many pharmas or biotechs, or academic groups for that matter, have that record?" Ho asks.

Ho has also increasingly focused on public health, particularly in China. He and his colleagues escorted Bill Clinton there last year. "At least in Asia it was quite a splash and people know what kind of impact that event had and who was really behind it," he says. Ho also assisted the Chinese government during the severe acute respiratory syndrome outbreaks, but says AIDS will remain his main focus. "I feel I should stay with the HIV/AIDS field," he says. "I'm too young to think about legacy, but I want to leave my mark on this field."

Apoorva Mandavilli, New York 